\title{
Effect of dietary fat saturation on lipid metabolism, arachidonic acid turnover and peritoneal macrophage oxidative stress in mice
}

L.B. Oliveros,

A.M. Videla and

M.S. Giménez

\author{
Laboratorio de Bioquimica Molecular, Departamento de Bioquimica y Ciencias \\ Biologicas, Faculdade de Quimica, Bioquimica y Farmacia, \\ Universidade Nacional de San Luis, San Luis, Argentina
}

\section{Correspondence \\ M.S. Gimenez \\ Av. Ejército de los Andes, 950 \\ 5700 San Luis \\ Argentina \\ Fax: +54-2652-43-1301 \\ E-mail: mgimenez@unsl.edu.ar or \\ lolive@unsl.edu.ar \\ Research supported by CONICET (PIP 4931) and by the Secretary \\ of Science and Technology of \\ San Luis University (Project 8104), \\ Argentina. \\ M.S. Gimenez a is member of CONICET (National Investigations Council of Science and Technology), Argentina.}

Received May 6, 2003

Accepted November 27, 2003

\begin{abstract}
We investigated the effects of a saturated fat diet on lipid metabolism and arachidonic acid (AA) turnover in mouse resident peritoneal macrophages. The pro-oxidative effect of this diet was also studied. Female C57BL/6 mice were weaned at 21 days of age and assigned to either the experimental diet containing coconut oil (COCO diet), or the control diet containing soybean oil as fat source $(10$ mice per group). The fat content of each diet was $15 \%(\mathrm{w} / \mathrm{w})$. Mice were fed for 6 weeks and then sacrificed. The concentration of total lipids, triglycerides, (LDL + VLDL)-cholesterol, thiobarbituric acid-reactive substances (TBARS) and reduced glutathione were increased in the plasma of mice fed the COCO diet, without changes in phospholipid or total cholesterol concentrations compared to control. The concentrations of total cholesterol, free and esterified cholesterol, triglycerides, and TBARS were increased in the macrophages of COCO-fed mice, while the content of total phospholipids did not change. The phospholipid composition showed an increase of phosphatidylcholine and a decrease of phosphatidylethanolamine. The $\left[{ }^{3} \mathrm{H}\right]$-AA distribution in the phospholipid classes showed an increase in phosphatidylcholine and phosphatidylethanolamine. Incorporation of $\left[{ }^{3} \mathrm{H}\right]$-cholesterol into the macrophages of $\mathrm{COCO}$-fed mice and into the cholesterol ester fraction was increased. The COCO diet did not affect $\left[{ }^{3} \mathrm{H}\right]$-AA uptake but induced an increase in $\left[{ }^{3} \mathrm{H}\right]-\mathrm{AA}$ release. The $\mathrm{COCO}$ diet also enhanced AA mobilization induced by lipopolysaccharide. These results indicate that the $\mathrm{COCO}$ diet, high in saturated fatty acids, alters the lipid metabolism and AA turnover of peritoneal macrophages in female mice and also produces a significant degree of oxidative stress.
\end{abstract}

\section{Introduction}

Macrophages are immunoinflammatory cells characterized by an active energetic, oxidative and lipid metabolism. Several func-
Key words

- Peritoneal macrophage

- Coconut oil

- Soybean oil

- Lipids

- Oxidative stress

- Arachidonic acid 
vating factor) (1). The phospholipids of mouse peritoneal macrophages are highly enriched with arachidonic acid (AA) (2) and have a selective $85-\mathrm{kDa}$ cytosolic phospholipase $\mathrm{A}_{2}\left(\mathrm{cPLA}_{2}\right)$, a phosphatide 2-acylhydrolase (EC 3.1.1.4) that hydrolyzes the sn-2 arachidonyl ester linked to phosphoglycerides, producing free AA and lysophospholipids (3). Free AA can also act as second messenger and as a substrate for inflammatory mediator synthesis (2). In macrophages, $\mathrm{AA}$ and reactive oxygen species (ROS) release is induced by diverse agonists including calcium ionophores, phorbol 12-myristate 13-acetate, okadaic acid, opsonized zymosan, and bacterial lipopolysaccharide (LPS) (4), and these releases are correlated with activation of $\mathrm{CPLA}_{2}$ and NADPH oxidase (5). Macrophages play an important role in the processing of cholesterol derived from the metabolism of plasma lipoproteins as well as in the reutilization of cholesterol from damaged or senescent cells. There is a well-documented association between dietary saturated fat intake, elevated plasma LDLcholesterol levels, and increased risk of cardiovascular disease $(6,7)$.

It is known that changes in dietary fat can alter the tissue fatty acid composition and distribution but the extent and nature of these changes can vary markedly according to tissue site and cell type. The amount, not the position, of dietary 16:0 of coconut oil and palm oil determines the $16: 0$ content of piglet adipose tissue (8). Fatty acids play a role in modulating cell metabolism and signal transduction. Indeed, fatty acid-rich diets (with $20 \%$ by weight of hydrogenated coconut oil or unsaturated olive, safflower, or menhaden oil) can lead to changes in phagocytosis, enzyme activity (hexokinase, citrate synthase, glucose-6-phosphate dehydrogenase, and glutaminase), and production of cytokines (interleukin-1 and -6, tumor necrosis factor- $\alpha$ ), eicosanoids (prostaglandins $\mathrm{PGE}_{2}$ and 6-keto-PGF ${ }_{1 \alpha}$ ), and reactive species (superoxide, hydrogen peroxide, and nitric oxide) in resident and thioglycolateelicited macrophages (9-11).

It is known that the oxidant-antioxidant balance is critical for immune cell function because it maintains the integrity and functionality of the cell membrane, cellular proteins and nucleic acids. Moreover, this balance is important in controlling signal transduction and gene expression. Immune cells are particularly sensitive to oxidative stress because of the high percent of polyunsaturated fatty acids in their plasma membranes and a higher production of ROS, which is part of their normal function (12). Dietary lipid plays a key role in determining cellular susceptibility to oxidative stress. It has been concluded that changes in fat level and fatty acid composition of the diet alter the mucosal cell membrane lipid composition in the rat large intestine and influences the susceptibility of mucosal cell lipid to peroxidation (13). Membrane lipids can be oxidized by an autocatalytic free radical reaction whereby polyunsaturated fatty acids and phospholipids undergo degradation by a chain reaction that results in the formation of lipoperoxides, various aldehydes (e.g., malondialdehyde, MDA), and short chain hydrocarbons (e.g., ethane, propane, pentane), among others (12). Oxidative stress induced by dietary saturated fatty acids can alter cell membranes, modifying the lipid composition and function of peritoneal macrophages $(11,14)$. Glutathione (GSH), a cysteine-containing tripeptide, is the most abundant non-protein thiol in mammalian cells and plays an important role in the scavenging of ROS and free radicals and in the regulation of AA metabolism (15). Because redox status depends on the cellular balance between pro-oxidant and antioxidant factors, GSH could have an important effect on AA turnover in macrophages.

The major goal of this study was to investigate the effects of dietary saturated fat on the lipid composition, lipid peroxidation and AA turnover of female mouse resident peritoneal macrophages. 


\section{Material and Methods}

\section{Chemicals}

Phenol red-free Dulbecco's modified Eagle's medium (DMEM) and fetal calf serum (FCS) were purchased from Gibco BRL (Life Technologies Inc., Rockville, MD, USA). [1,2- $\left.{ }^{3} \mathrm{H}(\mathrm{N})\right]$-cholesterol (9.25 MBq/ g) was purchased from Dupont $\left(\mathrm{NEN}^{\mathrm{TM}}\right.$, New England Nuclear Life Science Products Inc., Boston, MA, USA). [5,6,8,9,11,12,14,15$\left.{ }^{3} \mathrm{H}\right]$-AA ( $\left[{ }^{3} \mathrm{H}\right]$-delta4 AA, $\left.185 \mathrm{Ci} / \mathrm{mmol}\right)$ was obtained from $\mathrm{NEN}^{\mathrm{TM}}$. Antibiotics, LPS from Escherichia coli serotype O55:B5 and lipid standards were acquired from Sigma (St. Louis, MO, USA). The plasma concentrations of total lipids, total cholesterol, HDLcholesterol, phospholipids and triglyceride were determined by enzymatic methods using kits from Boehringer Mannheim Diagnostics (Indianapolis, IN, USA). All other chemicals were of reagent grade and were purchased from Merck Laboratory (Buenos Aires, Argentina).

\section{Animals and diets}

Adult female C57BL/6 mice bred in our animal facilities and maintained in a humidity- and temperature- $\left(21-23^{\circ} \mathrm{C}\right)$ controlled environment with a 12-h light-dark cycle were used. The mice came from dams maintained on standard lab chow and were weaned at 21 days of age and immediately assigned randomly to either the experimental diet containing coconut oil (COCO diet), or the control diet containing soybean oil as fat source. Mice were housed in individual stainless steel cages and given free access to food and water throughout the 6 weeks of the experimental period. Diets were isocaloric of identical compositions except for the fat type. The fat content was $15 \%(\mathrm{w} / \mathrm{w})$ in both the control and $\mathrm{COCO}$ diets. The fatty acid composition of the diets was as follows: the control diet contained 12:0, 0.1\%; 14:0, trace $(\leq 0.1 \%) ; 16: 0,9.1 \% ; 16: 1(n-7), 0.2 \% ; 18: 0$, $5.9 \% ; 18: 1(n-9), 23.0 \% ; 18: 2(n-6), 53.2 \%$; $18: 3(n-3), 8.4 \%$, and the COCO diet contained: $12: 0,41.6 \% ; 14: 0,18.6 \% ; 16: 0$, $10.9 \% ; 18: 0,13.6 \% ; 18: 1(n-9), 2.7 \% ; 18: 2(n-$ 6), $2.1 \% ; 18: 3(n-3), 0.2 \%$. Coconut oil also contained approximately $8 \%$ caprylic $(8: 0)$ and $6 \%$ capric (10:0) acids (13), but fatty acids shorter than 12:0 were not resolved under our working conditions. Diets were prepared according to the AIN-93 for laboratory rodents (16). The oils were stored in opaque containers at $-70^{\circ} \mathrm{C}$ and the diets were prepared fresh daily by the addition of the appropriate amount of oil to a mix of the other dietary components. Body weight and food intake were recorded daily.

\section{Plasma determinations}

Mice were killed by decapitation between 8:00 and 9:00 am of the last experimental day. Blood was collected into EDTA-coated tubes (150 mg EDTA/l in $9 \mathrm{~g} \mathrm{NaCl} / \mathrm{l}$ ), and plasma was prepared by centrifugation. Plasma lipids were determined by enzymatic methods using Boehringer kits and fresh plasma from mice that had been deprived of food for $12 \mathrm{~h}$. The difference between total cholesterol and HDLcholesterol was assumed to be the cholesterol associated with LDL + VLDL.

\section{Isolation and culture of peritoneal macrophages}

Resident peritoneal macrophages were prepared in an LPS-free system as described previously (17). Peritoneal cells were prepared by washing the peritoneal cavity with ice-cold $\mathrm{Ca}^{2+}$-, $\mathrm{Mg}^{2+}$ - and phenol red-free Hank's balanced salt solution (HBSS) containing $1 \mathrm{mM}$ EDTA and 1\% BSA. After washing twice with cold HBSS, the peritoneal cells were suspended in DMEM and $2 \mathrm{x}$ $10^{6}$ cells were added to each well of 12-well culture plates (Corning Glass Works, Corning, NY, USA). After incubation for $2 \mathrm{~h}$ at 
$37^{\circ} \mathrm{C}$ in a $95 \%$ air $/ 5 \% \mathrm{CO}_{2}$ atmosphere, nonadherent cells were removed by vigorously washing three times with ice-cold HBSS. Differential counts of the adherent cells used for the experiments were determined microscopically after Giemsa and nonspecific esterase staining. Resident preparations were $95 \%$ macrophages. Macrophages were further cultured for $24 \mathrm{~h}$ in phenol red-free DMEM supplemented with 10\% FCS, 50 $\mu \mathrm{g} / \mathrm{ml}$ gentamicin, $50 \mu \mathrm{g} / \mathrm{ml}$ penicillin, and $50 \mu \mathrm{g} / \mathrm{ml}$ fungizone. The amount of macrophage protein of each well was measured by the method of Wang and Smith (18).

To obtain the macrophage suspensions and determine cell viability, adherent cells were harvested by incubation at $4^{\circ} \mathrm{C}$ with 1 $\mathrm{ml}$ of cold $5 \mathrm{mM}$ EDTA $/ 5 \%$ FCS in HBSS. The cell suspension was aspirated and centrifuged at $200 \mathrm{~g}$ for $10 \mathrm{~min}$ at $4^{\circ} \mathrm{C}$ and the cells were then washed with cold HBSS. The pellet was resuspended in $1 \mathrm{ml} \mathrm{HBSS}$ and 10 $\mu l$ of the cell suspension was mixed with the same volume of $0.1 \%$ Trypan blue in PBS. After 3-min incubation on ice, the cells were screened for viability by light microscopy. Cell viability evaluated by Trypan blue exclusion was never below 95\%. When necessary, $250 \mu \mathrm{l}$ of the washed cell suspension ( $4 \times 10^{6}$ cells $/ \mathrm{ml}$ of HBSS) was treated with $250 \mu \mathrm{l}$ of lysis solution (20 mM Tris-succinate, $\mathrm{pH} 7.8$, containing a protease inhibitor cocktail and $0.1 \%$ Triton X-100).

\section{Lipid determinations}

A macrophage suspension containing $4 \mathrm{x}$ $10^{6}$ cells was centrifuged and lipids were extracted with chloroform:methanol (2:1) from the cell pellet according to the method of Folch et al. (19). An aliquot of the lipid extracts was used to determine total cholesterol, and another one to separate the different lipid fractions (phospholipids, triglyceride, free cholesterol and esterified cholesterol) by thin-layer chromatography (TLC) using plates coated with silica gel G (Merck), with an $n$-hexane:diethyl ether:acetic acid $(80: 20: 1, v / v / v)$ solvent system. Lipids were detected by exposing the plates to iodine vapors. After eluting the scraped bands, aliquots were used for mass determination according to the methods of Rouser et al. (20) for phospholipids, of Sardesai and Manning (21) for triglyceride, and of Zak et al. (22) for free and esterified cholesterol. On average, $90 \%$ of the cholesterol mass was recovered by TLC. Phospholipids were separated into component species by TLC using silica gel $\mathrm{G}$ plates and chloroform:methanol: water $(65: 25: 4, \mathrm{v} / \mathrm{v})$ as the solvent system. The individual phospholipids were identified, recovered and quantified for phosphorus content as indicated above. The results are reported as percentage of total phospholipid phosphorus content. The position of neutral lipids and individual phospholipids was determined using the respective standards.

\section{Incorporation of $\left[{ }^{3} \mathrm{H}\right]$-cholesterol by peritoneal macrophages}

After $24 \mathrm{~h}$ of culture the peritoneal macrophages $\left(2 \times 10^{6}\right.$ cells $)$ were incubated with $0.125 \mu \mathrm{Ci}$ of $\left[{ }^{3} \mathrm{H}\right]$-cholesterol for $60 \mathrm{~min}$ at $37^{\circ} \mathrm{C}$ in a $95 \%$ air $/ 5 \% \mathrm{CO}_{2}$ atmosphere. Lipid extraction and separation of cholesterol and cholesterol ester bands were carried out by TLC as indicated above. Bands were scraped off and their radioactivity was measured with a Beckman LS 100 C liquid scintillation counter (ESANCO SRL, Buenos Aires, Argentina). The results are reported as pmol $\left[{ }^{3} \mathrm{H}\right]$ incorporated $\mathrm{h}^{-1} \mathrm{mg}$ protein ${ }^{-1}$.

\section{Arachidonic acid uptake and release}

Macrophage monolayers $\left(2 \times 10^{6}\right.$ cells $)$ were washed three times with HBSS and incubated in $1 \mathrm{ml}$ DMEM containing $1 \mu \mathrm{Ci}$ $\left[{ }^{3} \mathrm{H}\right]$-delta4 AA for 30, 60, 120, 240 and 360 min at $37^{\circ} \mathrm{C}$. The cell cultures were then washed with HBSS containing $0.5 \%$ BSA to remove non-incorporated $\left[{ }^{3} \mathrm{H}\right]$-AA. At the 
end of each incubation the macrophage monolayers were treated with lysis solution as described earlier (see Isolation and culture of peritoneal macrophages). Finally, the radioactivity present in the solubilized cells was measured by scintillation counting.

In the AA release experiments, cell monolayers were labeled with $\left[{ }^{3} \mathrm{H}\right]$-delta4 AA for $6 \mathrm{~h}$ at $37^{\circ} \mathrm{C}$. The macrophages used in these studies incorporated $41 \pm 5 \%$ of $\left[{ }^{3} \mathrm{H}\right]$-AA added to the culture medium, and no significant variations in cells from COCO-fed mice were observed compared to those from mice receiving the control diet. The cell monolayers were then washed three times with HBSS containing $0.5 \%$ BSA to remove non-incorporated $\left[{ }^{3} \mathrm{H}\right]$-AA and stimulated in $1 \mathrm{ml}$ HBSS containing $10 \mathrm{mM}$ glucose, $1 \mathrm{mM}$ $\mathrm{CaCl}_{2}, 1 \mathrm{mM} \mathrm{MgCl}_{2}$, antibiotics, $0.5 \%$ BSA (to prevent AA re-esterification) and LPS (1 $\mu \mathrm{g} / \mathrm{ml})$. After $3 \mathrm{~h}$ of incubation, the medium was removed and the amount of radioactivity in the cells and medium was measured as indicated above. The released radioactivity was determined and is reported as percent cell-incorporated $\left[{ }^{3} \mathrm{H}\right]$-AA, which was determined in solubilized cells.

\section{Arachidonic acid distribution in phospholipid classes}

After $6 \mathrm{~h}$ of incubation in medium containing $0.1 \mu \mathrm{Ci}\left[{ }^{3} \mathrm{H}\right]$-delta4 AA, total lipids from macrophage monolayers were extracted and total and individual phospholipids were separated by TLC (see Lipid determinations). Their radioactivity was measured as described above. The $\left[{ }^{3} \mathrm{H}\right]-\mathrm{AA}$ of individual phospholipids is reported as percent $\left[{ }^{3} \mathrm{H}\right]$-AA incorporated into total phospholipids.

\section{TBARS and GSH determinations}

Thiobarbituric acid-reactive substances (TBARS) were measured as described by Jentzsch et al. (23). Briefly, serum (200 $\mu 1)$ or standard (MDA prepared by hydrolysis of tetramethoxypropane) was mixed with $25 \mu 1$ butylated hydroxytoluene in ethanol $(0.3$ $\mu \mathrm{mol} / \mathrm{l})$ and $200 \mu \mathrm{l}$ orthophosphoric acid $(0.2 \mu \mathrm{mol} / \mathrm{l})$. Thiobarbituric acid reagent ( 25 $\mu \mathrm{l}$ at $0.11 \mathrm{~mol} / \mathrm{l}$, dissolved in $\mathrm{NaOH}$ ) was added and the reaction mixture was incubated at $90^{\circ} \mathrm{C}$ for $45 \mathrm{~min}$. TBARS were extracted with $500 \mu \mathrm{l}$ n-butanol. Absorption was read at 535 and $572 \mathrm{~nm}$ to correct for baseline absorption in a Beckman microplate reader (Bio-Rad, Alfatron, Buenos Aires, Argentina). MDA equivalents were calculated using the difference in absorption at the two wavelengths and quantified with the aid of a calibration curve. Total GSH $(\mathrm{GSH}+\mathrm{GSSG})$ was extracted from macrophages with $10 \%$ perchloric acid. The GSH content in the cells was measured using an enzymatic method (24), which is based on the catalytic action of GSH in the reduction of 5,5'-dithiobis (2-nitrobenzoic acid) by means of the GSH reductase system. The GSH extracted from cells was mostly GSH and the content of the oxidized form (GSSG) was less than $10 \%$ of total GSH under the present experimental conditions.

\section{Statistical analysis}

Data are reported as mean \pm SD and were analyzed statistically by the Student $t$-test for noncorrelated data. Statistical significance was accepted at $\mathrm{P}<0.05$.

\section{Results}

\section{Growth, food intake and plasma concentrations of lipids, TBARS and GSH}

The initial body weight of the mice in both dietary groups was the same $(8 \pm 0.6 \mathrm{~g})$. At the time of sacrifice, there was no significant effect of the saturated fatty acid dietary manipulation on the body weight gain of the mice fed the COCO diet compared to that of mice fed the control diet $(12.70 \pm 0.82 v s$ 
$14.01 \pm 0.61 \mathrm{~g})$ after 6 weeks of dietary treatment. As the mice grew the daily food consumption increased similarly in both dietary groups (data not shown). Plasma total lipids, (LDL + VLDL)-cholesterol fraction

\begin{tabular}{|c|c|c|}
\hline & Control diet & COCO diet \\
\hline \multicolumn{3}{|l|}{ Plasma lipids (g/l) } \\
\hline Total lipids & $5.38 \pm 0.22$ & $7.48 \pm 0.19 *$ \\
\hline Triglyceride & $1.49 \pm 0.08$ & $2.15 \pm 0.17^{*}$ \\
\hline Total cholesterol & $0.88 \pm 0.06$ & $1.02 \pm 0.07$ \\
\hline HDL-cholesterol & $0.57 \pm 0.05$ & $0.54 \pm 0.04$ \\
\hline $\begin{array}{l}\text { (LDL + VLDL)- } \\
\text { cholesterol }\end{array}$ & $0.31 \pm 0.03$ & $0.48 \pm 0.04^{*}$ \\
\hline Phospholipids & $0.79 \pm 0.04$ & $0.80 \pm 0.06$ \\
\hline $\begin{array}{l}\text { TBARS (nmol } \\
\text { MDA/ml) }\end{array}$ & $6.52 \pm 0.78$ & $10.55 \pm 1.03^{*}$ \\
\hline $\mathrm{GSH}(\mu \mathrm{Eq} / \mathrm{ml})$ & $0.88 \pm 0.02$ & $1.34 \pm 0.03^{*}$ \\
\hline
\end{tabular}

Data are reported as means \pm SEM for 10 mice/ group. NS = not significant.

${ }^{*} \mathrm{P}<0.01$ compared to the control diet (Student $t$ test).

\begin{tabular}{|c|c|c|}
\hline & Control diet & COCO diet \\
\hline \multicolumn{3}{|c|}{ Lipids ( $\mu \mathrm{g} / \mathrm{mg}$ protein) } \\
\hline $\mathrm{TC}$ & $86.20 \pm 3.24$ & $117.53 \pm 5.20^{*}$ \\
\hline $\mathrm{FC}$ & $78.74 \pm 1.80$ & $105.98 \pm 4.79 *$ \\
\hline $\mathrm{EC}$ & $7.46 \pm 0.46$ & $11.55 \pm 0.50 *$ \\
\hline Triglyceride & $73.08 \pm 1.87$ & $90.22 \pm 2.05^{*}$ \\
\hline Phospholipids & $219.46 \pm 8.77$ & $225.10 \pm 10.25$ \\
\hline FC/EC & $10.51 \pm 0.42$ & $9.13 \pm 0.81$ \\
\hline TC/phospholipids & $0.40 \pm 0.08$ & $0.52 \pm 0.09$ \\
\hline $\begin{array}{l}\text { Protein }\left(\mathrm{mg} / 10^{7}\right. \\
\text { cells) }\end{array}$ & $1.09 \pm 0.14$ & $1.12 \pm 0.17$ \\
\hline $\begin{array}{l}\text { TBARS (nmol } \\
\text { MDA/mg protein) }\end{array}$ & $6.72 \pm 0.57$ & $10.88 \pm 0.42^{*}$ \\
\hline \multicolumn{3}{|c|}{$\begin{array}{l}\text { Data are reported as means } \pm \text { SEM of four experi- } \\
\text { ments with three COCO- and control-fed mice each. } \\
\text { Chemical determinations were performed on two } \\
\text { separate cell preparations from each animal. EC = } \\
\text { esterified cholesterol; FC = free cholesterol; TC = } \\
\text { total cholesterol. } \\
{ }^{*} \mathrm{P}<0.01 \text { compared to the control diet (Student } t- \\
\text { test). }\end{array}$} \\
\hline
\end{tabular}

and triglyceride concentrations were significantly higher in COCO-fed mice than in controls. There were no differences in plasma phospholipid concentrations between the dietary groups. The plasma TBARS and GSH levels were significantly higher in the $\mathrm{COCO}-$ fed group compared to control $(\mathrm{P}<0.001$; Table 1).

\section{Effect of the diet on the macrophage lipid composition and TBARS content}

As shown in Table 2, the concentration of total cholesterol (which was related to the increased free and esterified cholesterol fractions) and triglyceride increased in the peritoneal macrophages of COCO-fed mice compared to control. Consequently, the free cholesterol/esterified cholesterol ratio did not change. In addition to the changes in lipid composition of macrophages of mice fed the COCO diet, cell TBARS levels also increased compared to those of mice fed the control diet. Cell protein concentration was not affected by the diet.

\section{Effect of the diet on the phospholipid pattern in peritoneal macrophages}

On a percentage basis, the phospholipid composition was modified in macrophages of mice fed the COCO diet compared with those fed the control diet. In the COCO-fed group phosphatidylcholine (PC) increased and phosphatidylethanolamine (PE) decreased, while phosphatidylglycerol and phosphatidylserine plus phosphatidylinositol did not change compared to the control group, indicating that dietary saturated fat can modify the phospholipid compositions of resident peritoneal macrophages in female mice (Figure 1).

$\left[{ }^{3} \mathrm{H}\right]$-cholesterol incorporation and estimation of cholesterol esterification in vitro

The $\left[{ }^{3} \mathrm{H}\right]$-cholesterol incorporated by 
macrophages at $60 \mathrm{~min}$ of incubation was increased by $28 \%$ in the mice fed the COCO diet when compared with that of mice fed the control diet. We detected a significant increase in the radiolabeled cholesterol esters of macrophages from mice fed the $\mathrm{COCO}$ diet (Figure 2).

\section{Arachidonic acid uptake and release and distribution into phospholipid classes}

The incorporation of labeled AA by peritoneal macrophages of both dietary groups showed a time-dependent increase up to 360 min. The COCO diet did not affect the uptake of $\left[{ }^{3} \mathrm{H}\right]$-AA (Figure 3). Peritoneal macrophages from $\mathrm{COCO}$-fed mice caused a significant increase in $\left[{ }^{3} \mathrm{H}\right]$-AA release in the absence of LPS in the incubation medium with respect to control cells. The addition of LPS to the medium caused a marked increase in $\left[{ }^{3} \mathrm{H}\right]-A A$ release from macrophages from COCO-fed mice compared to the respective control cells (Figure 4). Macrophages of COCO-fed and control mice did not show significant variations in AA incorporation into total phospholipids (data not shown). The distribution of $\left[{ }^{3} \mathrm{H}\right]$-AA into the major classes of phospholipids demonstrated that macrophages of COCO-fed mice incorporate more label in PC and PE than those of control macrophages (Figure 5).

\section{Discussion}

The present results provide experimental evidence for the effects of coconut oil in the diet on AA turnover, lipid peroxidation and lipid contents in resident peritoneal macrophages from female mice. Mice fed the COCO diet had significantly higher fasting plasma total lipids compared to control, which is associated with the increase of triglyceride levels. High plasma triglyceride concentrations have been demonstrated in subjects consuming a saturated fat diet (25) and have also been associated with the VLDL

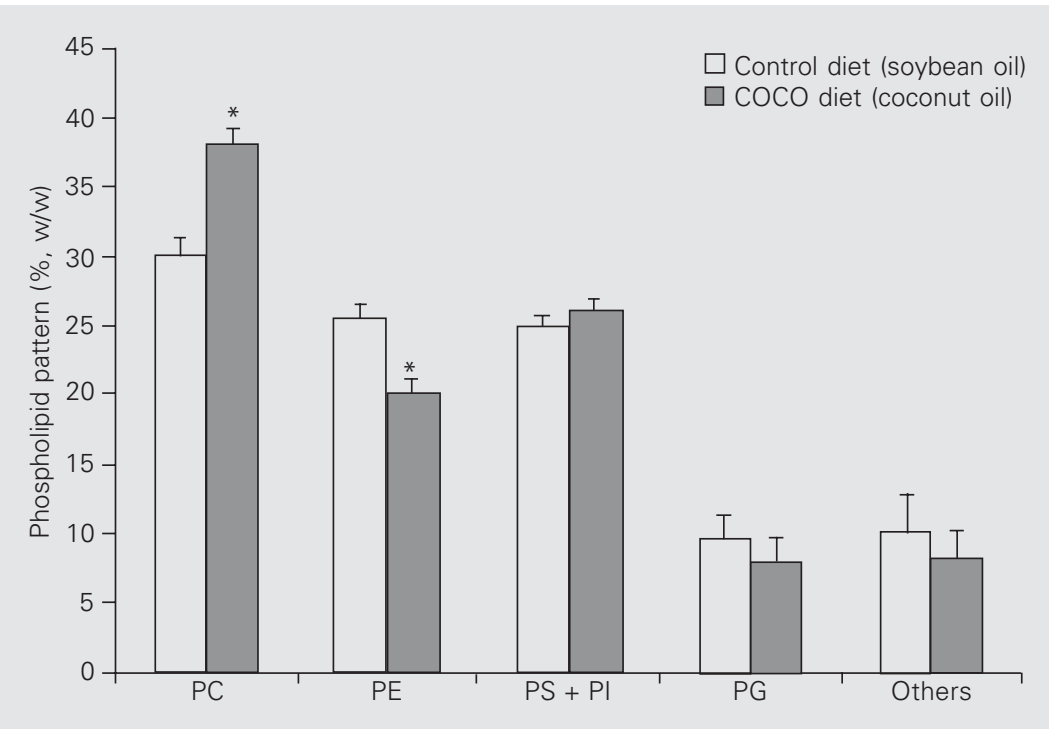

Figure 1. Phospholipid pattern of mouse peritoneal macrophages. $P C=$ phosphatidylcholine; $P E=$ phosphatidylethanolamine; $P G=$ phosphatidylglycerol; $P S+P I=$ phosphatidylser ine plus phosphatidylinositol. Data are reported as means \pm SEM of three experiments with three COCO- and control-fed mice each. Chemical determinations were performed on two separate cell preparations from each animal. ${ }^{*} \mathrm{P}<0.05$ compared to the control diet (Student $t$-test).

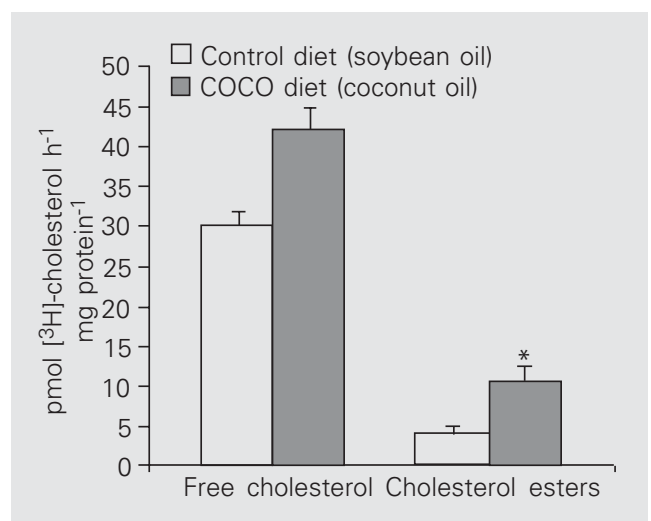

Figure 2. Cholesterol incorporation in mouse peritoneal macrophages. Data are reported as means \pm SEM of three experiments with three COCO- and control-fed mice each. The incorporation assay was performed on two separate cell preparations per animal. ${ }^{*} \mathrm{P}<$ 0.05 compared to control (Student $t$-test).

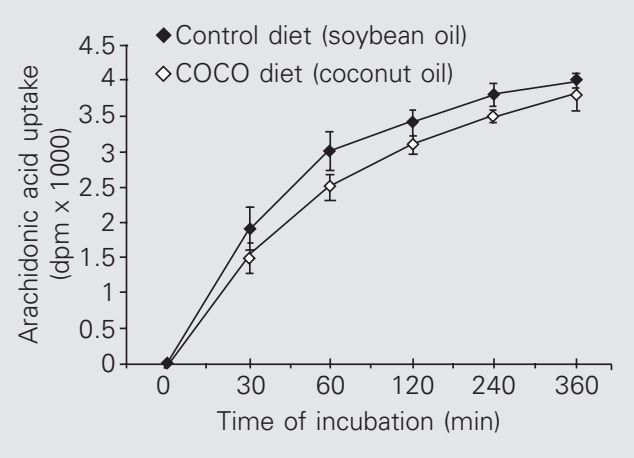

Figure 3. Kinetics of arachidonic acid uptake by peritoneal macrophages from mice fed the COCO diet and those fed the control diet. Data are reported as means \pm SEM of three experiments in duplicate. 
levels in hamsters fed a 14:0-enriched diet (26). The hypertriglyceridemia produced by the COCO diet could be caused by enhanced liver VLDL-triglyceride secretion into the circulation, since other investigators have demonstrated an increase of hepatic VLDL production in guinea pigs fed a diet containing $15 \%(\mathrm{w} / \mathrm{w})$ palm kernel oil, which con-

Figure 4. Arachidonic acid mobilization from peritoneal macrophages. Cells were incubated in DMEM containing $1 \mu \mathrm{Ci}\left[{ }^{3} \mathrm{H}\right]-$ arachidonic acid for $6 \mathrm{~h}$ and then exposed to LPS for $3 \mathrm{~h}$. Arachidonic acid mobilization was measured as described in Material and Methods. Data are reported as means \pm SEM of three experiments with three $\mathrm{COCO}$ and control-fed mice each, using two separate cell preparations per animal. ${ }^{*} P<0.001$ compared to medium without LPS; $+P<$ 0.001 compared to the control diet (two-way ANOVA).

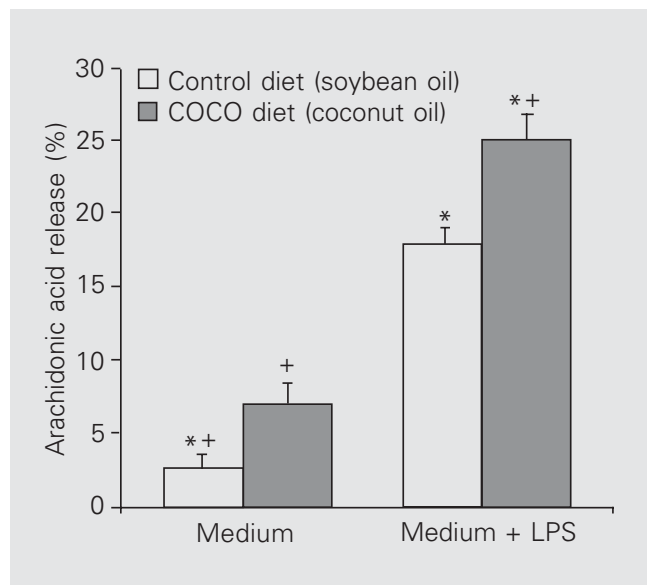

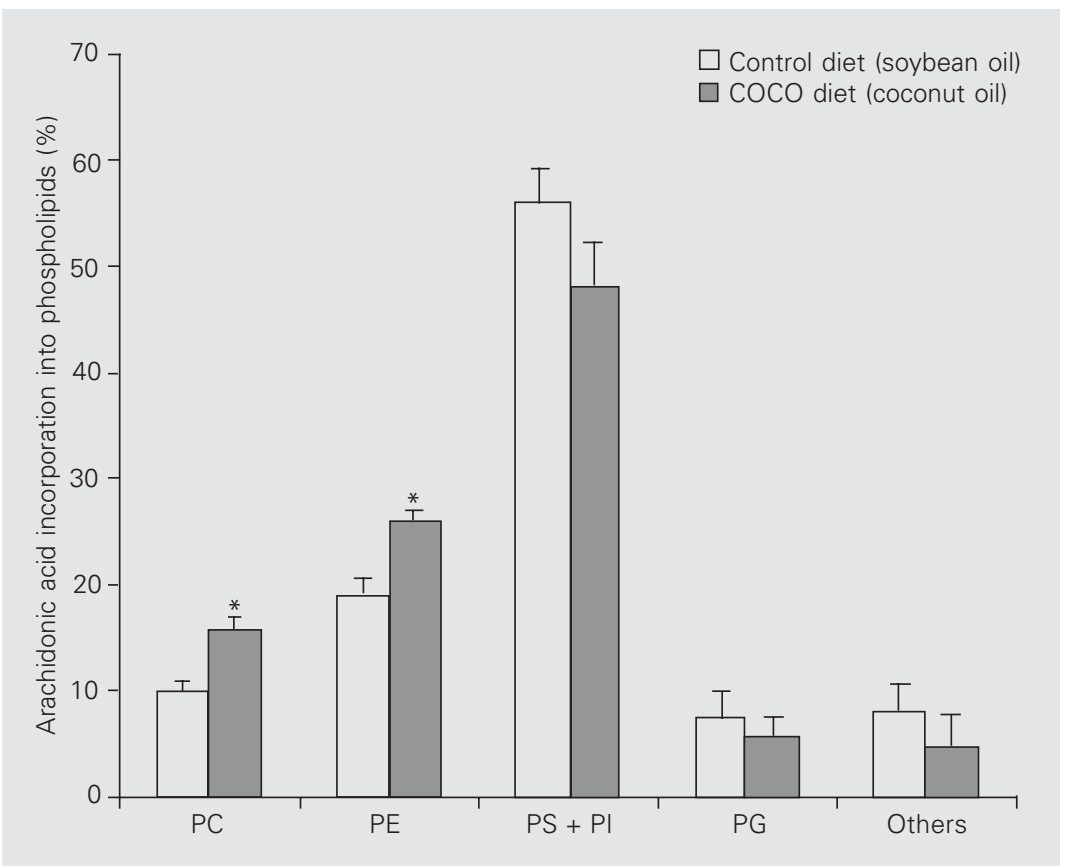

Figure 5. Arachidonic acid incorporation into the major phospholipid classes. $\mathrm{PC}=$ phosphatidylcholine; $\mathrm{PE}=$ phosphatidylethanolamine; $\mathrm{PG}=$ phosphatidylglycerol; $\mathrm{PS}+\mathrm{PI}=$ phosphatidylserine plus phosphatidylinositol. Data are reported as means \pm SEM of three experiments with three COCO- and control-fed mice each. Chemical determinations were performed on two separate cell preparations per animal. ${ }^{*} \mathrm{P}<0.001$ compared to the control diet (Student $t$-test). tains more than $90 \%$ saturated fatty acids (27). In contrast, it has been shown that linoleic acid-enriched diets have a hypocholesterolemic potential due to the fact that cholesterol is taken up rapidly by the liver and other tissues (28).

The $\mathrm{COCO}$ diet induced important changes in the lipid composition of peritoneal macrophages. Macrophages can acquire cholesterol both by endogenous synthesis and by uptake of cholesterol-containing extracellular material (7). The increase in the incorporation of $\left[{ }^{3} \mathrm{H}\right]$-cholesterol into macrophages of COCO-fed mice and also in the cholesterol ester fraction compared to control indicates that exogenous cholesterol is effectively taken up and esterified by these cells. This is in agreement with published data showing that the accumulation of cholesterol in cells leads to an increase in the mRNA level of acyl coenzyme A:cholesterol acyltransferase (ACAT) (29). Also, a significant fraction of arachidonate released from phospholipids, in particular from PC, could serve as substrate for ACAT in rat peritoneal macrophages (30). Accordingly, there was an increase of $\left[{ }^{3} \mathrm{H}\right]$-AA mobilization in macrophages of COCO-fed mice. Under normal conditions, peritoneal macrophages contain a very small amount of esterified cholesterol but this amount increases when macrophages are activated (31). The decrease in $\left[{ }^{3} \mathrm{H}\right]$ incorporated into free cholesterol suggests a feedback suppression of cholesterol synthesis by the sterol end-products of the pathway. In addition, it has been shown that human monocyte-macrophages accumulate cholesterol ester in lipid droplets when they are incubated with microcrystalline cholesterol or acetylated LDL and that the presence of lipid droplets is consistent with the fact that macrophages contain triglycerides $(6,32)$.

Similarly, we found an increase in triglyceride concentration in macrophages from COCO-fed mice compared to those from control mice. This is probably a direct conse- 
quence of the metabolic changes induced by the $\mathrm{COCO}$ diet in the peritoneal macrophages. $\mathrm{PC}$ is the major phospholipid in peritoneal macrophages (2) and it is known that free cholesterol increases PC synthesis by activation of cytosine triphosphate:phosphocholine cytidylyltransferase (CTP-CT), an enzyme which regulates PC synthesis (33). Thus, the high concentration of free cholesterol observed in macrophages of COCOfed mice may be responsible, at least in part, for the PC increase. The decrease in PE content and also the distribution of $\left[{ }^{3} \mathrm{H}\right]-\mathrm{AA}$ into $\mathrm{PC}$ and $\mathrm{PE}$ can be an adaptive cellular response in order to maintain phospholipid homeostasis. It has been demonstrated that in P388D1 macrophage-like cells the phospholipid pool constitutes the primary metabolic fate of the delta4-AA via a remodeling pathway (34).

The increased TBARS concentration in macrophages and plasma from mice fed the $\mathrm{COCO}$ diet in relation to those fed the control diet may be associated with lipid peroxidation. TBARS have been included in the products of peroxidation, which are considered to depend on the basic oxidizable lipid/ antioxidant relationship (35). Therefore, we cannot exclude the possibility that the increase in TBARS may be associated with the increase in lipid content induced by the COCO diet. Additionally, plasma GSH levels were increased in these animals. It has been shown that fatty acid-rich diets containing $20 \%$ by weight of hydrogenated coconut oil increase the production of ROS in resident rodent macrophages (36). In addition, it is known that mammalian cells respond to oxidative stress by several mechanisms, including GSH production (37). GSH can react with electrophilic or oxidizing spe- cies, protects protein thiol groups from oxidation, serves as substrate for many enzymes including GSH peroxidase, GSH reductase and GSH-S-transferase, and may participate in the detoxification of ROS. Thus, in our experimental model, the increase in plasma GSH may reflect an adaptive change in response to oxidative stress induced by a saturated fat diet. It is possible that the oxidative stress process is operating in animals exposed to saturated fat in the diet as a whole.

The increase in AA release observed in macrophages of COCO-fed mice suggests that activated macrophages would lead to an increased availability of free AA, which can be used to synthesize eicosanoids (1). In contrast, it has been shown that fish oil diets induce a decrease in $\left[{ }^{3} \mathrm{H}\right]$-AA mobilization in rat resident peritoneal macrophages treated with proinflammatory agents (38). In addition, the oxidative stress induced by exposure of vascular smooth muscle cells to $\mathrm{H}_{2} \mathrm{O}_{2}$ increases AA release (39). Gijón and Leslie (5) reported that AA release and eicosanoid production in response to agonists are dramatically reduced in resident peritoneal macrophages isolated from $\mathrm{cPLA}_{2}$ knockout mice. Furthermore, the role of $\mathrm{cPLA}_{2}$ in the mobilization of fatty acid damage by oxidative stress in cell membranes has been considered to be a cellular response to oxidative stress stimuli (40).

The present findings show that coconut oil in the diet modifies AA turnover and lipid metabolism and also provide evidence of the pro-oxidative effect of this saturated fat diet on the peritoneal macrophages of female mice. These metabolic consequences of the diet may alter the immunoinflammatory function of peritoneal macrophages, either directly or through changes in membrane fluidity.

\section{References}

1. Reilly MP, Lawson JA \& FitzGerald GA (1998). Eicosanoids and isoeicosanoids: indices of cellular function and oxidant stress. Journal of Nutrition, 128: 434S-438S.
2. Akoh CC \& Chapkin RS (1990). Composition of mouse peritoneal macrophage phospholipid molecular species. Lipids, 25: 613-617.

3. Wijkander J \& Sundler R (1989). A phospholipase $A_{2}$ hydrolyzing 
arachidonyl-phospholipid in mouse peritoneal macrophages. FEBS Letters, 244: 51-56.

4. Ramirez DC, Riera CM \& Gimenez MS (2001). Modulation of arachidonic acid turnover in macrophages by cadmium. Toxicology Letters, 122: 9-19.

5. Gijón MA \& Leslie CC (1999). Regulation of arachidonic acid release and cytosolic phospholipase $\mathrm{A}_{2}$ activation. Journal of Leukocyte Biology, 65: 330-336.

6. Kruth HS, Skarlatos SI, Lilly K, Chang J \& Ifrim I (1995). Sequestration of acetylated LDL and cholesterol crystal by human monocytederived macrophages. Journal of Cell Biology, 1: 133-145.

7. Reyk DM \& Jessup W (1999). The macrophage in atherosclerosis: modulation of cell function by sterols. Journal of Leukocyte Biology, 66: $557-561$.

8. Innis SM, Dyer R, Quinlan PT \& Diersen-Schade D (1996). Dietary triacylglycerol structure and saturated fat alter plasma and tissue fatty acids in piglets. Lipids, 31: 497-505.

9. Guimaraes ARP, Costa Rosa LFBP, Sitnik RH \& Curi R (1991). Effect of polyunsaturated (PUFA n-6) and saturated fatty acid-rich diets on macrophage metabolism and function. Biochemistry International, 23: 533-543.

10. Otton R, Graziola F, Hirata MH, Curi R \& Williams JF (1998). Dietary fats alter the activity and expression of glucose-6-phosphate dehydrogenase in rat lymphoid cells and tissues. Biochemistry and Molecular Biology International, 46: 529-536.

11. Peres CM, Procopio J, Costa M \& Curi R (1999). Thioglycolateelicited rat macrophages exhibit alterations in incorporation and oxidation of fatty acids. Lipids, 34: 1193-1197.

12. Knight JA (2000). Free radicals, antioxidants and the immune system. Annals of Clinical and Laboratory Science, 30: 145-158.

13. Turini ME, Thomson ABR \& Clandinin MT (1991). Lipid composition and peroxide levels of mucosal cells in the rat large intestine in relation to dietary fat. Lipids, 26: 431-440.

14. Lee JY, Sohn KH, Rhee SH \& Wang DH (2001). Saturated fatty acids, but not unsaturated fatty acids, induce the expression of cyclooxygenase-2 mediated through Toll-like receptor 4 . Journal of Biological Chemistry, 276: 16683-16689.

15. Wang W \& Ballatori N (1998). Endogenous glutathione conjugates: occurrence and biological functions. Pharmacological Reviews, 50: 335-352.

16. Reeves PG, Nielsen FH \& Fahey Jr GC (1993). AIN-93 purified diets for laboratory rodents: Final report of the American Institute of Nutrition ad hoc Writing Committee on the Reformulation of the AIN-76 Rodent Diet. Journal of Nutrition, 123: 1939-1951.

17. Prabst MJ, Hedegaad HB \& Johnston Jr RB (1982). Cultured human monocytes require exposure to bacterial products to maintain an optimal oxygen radical response. Journal of Immunology, 128: 123128.

18. Wang C-S \& Smith RL (1975). Lowry determination of protein in the presence of Triton X-100. Analytical Biochemistry, 63: 414-417.

19. Folch J, Less M \& Sloane-Stanley GH (1968). A simple method for the isolation and purification of total lipid from animal tissues. Journal of Biological Chemistry, 226: 497-509.

20. Rouser G, Fleischer S \& Yamamoto A (1970). Two dimensional thin layer chromatographic separation of polar lipids and determination of phospholipids by phosphorus analysis of spots. Lipids, 5: 494-496.

21. Sardesai VM \& Manning JA (1968). Determination of triglycerides in plasma and tissues. Clinical Chemistry, 14: 156-161.

22. Zak B, Moss N, Boyle AS \& Zlatkis A (1954). Reactions of certain unsaturated steroids with acid iron reagent. Analytical Chemistry, 26: $776-777$.
23. Jentzsch AM, Bachmann R, Forst $P$ \& Biesalski HK (1996). Improved analysis of malondialdehyde in human body fluids. Free Radical Biology and Medicine, 20: 251-256.

24. Akerboom TPM \& Sies H (1981). Assay of glutathione disulfide and glutathione mixed disulfides in biological samples. In: Colowick SP \& Kaplan NO (Editors), Methods in Enzymology. Vol. 77. Academic Press, Inc., New York, 373-382.

25. Mazier MJP \& Jones PJH (1997). Diet fat saturation and feeding state modulate rates of cholesterol synthesis in normolipidemic men. Journal of Nutrition, 127: 332-340.

26. Hassel CA, Mensing EA \& Gallaher DD (1997). Dietary stearic acid reduces plasma and hepatic cholesterol concentrations without increasing bile acid excretion in cholesterol-fed hamsters. Journal of Nutrition, 127: 1148-1155.

27. Abdel-Fattah G, Fernandez ML \& McNamara DJ (1998). Regulation of very low density lipoprotein apo B metabolism by dietary fat saturation and chain length in the guinea pig. Lipids, 33: 23-31.

28. Garg ML \& Blake R (1997). Cholesterol dynamics in rats fed diets containing either canola oil or sunflower oil. Nutrition Research, 3: 485-492.

29. Nishikawa K, Sato Y, Arai H \& Inoue K (1993). Mobilization of acyl chains from endogenous cellular phospholipids into cholesteryl esters during foam-cell formation in mouse peritoneal macrophages. Biochimica et Biophysica Acta, 1169: 257-263.

30. Pollaud C, Krause S, Lepert JC, Orfila C, Seguelas M, Festal D, Decerprit J \& Pipy B (1995). Acetylated low density lipoprotein inhibits the incorporation of arachidonic acid in phospholipids with a concomitant increase of cholesterol arachidonate in rat peritoneal macrophages. Biochimica et Biophysica Acta, 1259: 211-219.

31. Kerkhoff C, Beuck M, Threige-Rasmussen J, Spener F, Knudsen J \& Schmitz G (1997). Acyl-CoA binding protein (ACBP) regulates acylCoA:cholesterol acyltransferase (ACAT) in human mononuclear phagocytes. Biochimica et Biophysica Acta, 1346: 163-172.

32. Skarlatos SI, Rouis M, Chapman MJ \& Kruth HS (1993). Heterogeneity of cellular cholesteryl ester accumulation by human monocyte-derived macrophages. Atherosclerosis, 99: 229-240.

33. Henneberry AL, Wright MM \& McMaster CR (2002). The major sites of cellular phospholipid synthesis and molecular determinants of fatty acid and lipid head group specificity. Molecular Biology of the Cell, 13: 3148-3161.

34. Balsinde J \& Dennis EA (1996). The incorporation of arachidonic acid into triacylglycerol in P388D1 macrophage-like cells. European Journal of Biochemistry, 235: 480-485.

35. Tappel AL (1998). Models of antioxidant protection against biological oxidative damage. Lipids, 33: 947 (Letter to the Editor).

36. Yaqoob P \& Calder PC (1995). Effects of dietary lipid manipulation upon inflammatory mediator production by murine macrophages. Cellular Immunology, 163: 120-128.

37. MacNee W (2000). Oxidants-antioxidants and COPD. Chest, 117: 303S-317S

38. Mitjavila MT, Rodriguez MC, Saiz MP, Lloret S \& Moreno JJ (1996). Effect of degree of unsaturation in dietary fatty acids on arachidonic acid mobilization by peritoneal macrophages. Lipids, 31: 661-666.

39. Cane A, Breton M, Koumanov K, Béréziat G \& Colard O (1998). Oxidant-induced arachidonic acid release and impairment of fatty acid acylation in vascular smooth muscle cells. American Journal of Physiology, 274: C1040-C1046.

40. Ito H, Hasegawa K, Inaguma Y, Kozawa O, Asano T \& Kato K (1995). Modulation of the stress-induced synthesis of stress protein by phorbol ester and okadaic acid. Journal of Biochemistry, 118: 629634. 